ISSN : 2550-0198

\title{
PENYAMAAN PERSEPSI PEMBELAJARAN BAHASA INGGRIS ANTARA GURU BAHASA INGGRIS DAN WALI MURID MI AL-KIFAYAH PEKANBARU
}

\author{
Siti Niah*, Wandi Syahfutra, Edi Ismanto \\ *Pendidikan Bahasa Inggris, Fakultas Keguruan dan Ilmu Pendidikan \\ Email: sitiniah@umri.ac.id
}

\begin{abstract}
Abstrak
Persaingan global dalam berbagai bidang menuntut penguasaan kompetensi skill dan akademik yang memadai dan dapat dipertanggungjawabkan. Dalam upaya peningkatan kualitas sumber daya manusia didunia pendidikan, penguasaan bahasa asing, terutama bahasa Inggris, merupakan suatu hal yang sanga tpenting. Hal ini didasari atas bahasa Inggris adalah bahasa global yang digunakan pada era saat ini. Berdasarkan analisa yang telah dilakukan, pembelajaran Bahasa Inggris di Madrasah Ibtidaiyah Al-Kifayah Pekanbaru belum terlaksana dengan dengan baik, dan juga untuk persamaan persepsi dalam pengajaran antara guru Bahasa Inggris dan wali murid juga belum terjalin dengan baik. Atas dasar analisa tersebut maka diadakanlah pelatihan "Penyamaan Persepsi Pembelajaran Bahasa Inggris antara Guru dan Wali Murid bagi Anak Usia Sekolah Dasar" yang bertujuan untuk meningkatkan pemahaman siswa dalam menguasai Bahasa Inggris. Adapun metode yang digunakan dalam kegiatan pelatihan ini adalah metode ceramah, diskusi, dan role play. Adapun hasil Hasil kegiatan pengabdian kepada masyarakat ini mendapatkan sambutan yang sangat positif dari pihak mitra yakni Madrasah Ibtidaiyah Al-Kifayah Pekanbaru karena program ini sesuai dengan kebutuhan mereka. Bentuk sambutan yang sangat positif tersebut adalah terlihat dari partisipasi seluruh peserta pelatihan baik guru bahasa Inggris maupun wali murid yang hadir pada pelatihan tersebut sangat aktif dalam mengikuti seluruh proses kegiatan.
\end{abstract}

Kata kunci: Persepsi Pembelajaran, Bahasa Inggris, SD

\section{PENDAHULUAN}

Persaingan global dalam berbagai bidang menuntut penguasaan kompetensi skill dan akademik yang memadai dan dapat dipertanggungjawabkan. Dalam dunia pendidikan nasional Indonesia berbagai bentuk upaya telah dilakukan sebagai persiapan untuk menghadapi persaingan global ini, terutama untuk menghasilkan lulusan yang mampu bersaing, baik untuk melanjuktkan ke jenjang pendidikan yang lebih tinggi maupun dalam dunia kerja. Selain upaya-upaya yang dilakukan pemerintah melalui Departemen Pendidikan Nasional, berbagai upaya juga dilakukan secara mandiri oleh berbagai sekolah, baik dasar, menengah maupun pendidikan tinggi, antara lain dengan mencanangkan mutu pendidikan dan pengelolaan bertaraf internasional. Komitmen ini sebenarnya memiliki implikasi dan konsekuensi yang tidak kecil bagi sekolah/lembaga pendidikan yang yang bersangkutan. Banyak hal yang harus dilakukan, mulai dari pembenahan fasilitas, perbaikan kurikulum, pengembangan materi ajar, perbaikan sistem pengelolaan administrasi maupun akademik.

Dalam upaya peningkatan kualitas sumber daya manusia di dunia 
pendidikan, penguasaan bahasa asing, terutama bahasa Inggris, merupakan suatu hal yang sangat penting. Hal ini didasari atas bahasa Inggris adalah bahasa global yang digunakan pada era sekarang. Oleh karena itu, upaya untuk meningkatkan penguasaan bahasa Inggris bagi siswa merupakan bukti keseriusan sebuah sekolah untuk mewujudkan komitmen menuju sekolah bertaraf internasional.

Seperti halnya sekolah-sekolah dasar di kota Pekanbaru dan kotakota besar di Indonesia, Madrasah Ibtidaiyah Al-Kifayah Pekanbaru juga berbenah diri secara terusmenerus dalam rangka meningkatkan mutu pengajaran dan pengelolaan sebagai upaya untuk menuju sekolah yang dapat bersaing dengan sekolah yang sudah terlebih dulu ada dan berkualitas. Sudah menjadi komitmen sekolah tersebut untuk membekali siswanya kemampuan berbahasa Inggris sehingga mereka diharapkan memiliki daya saing yang tinggi untuk melanjutkan ke jenjang pendidikan berikutnya.

Pelatihan Bahasa Inggris 'Penyamaan Persepsi Pembelajaran Bahasa Inggris antara Guru Bahasa Inggris dan Wali Murid bagi Anak Sekolah Dasar' merupakan salah satu upaya yang dapat dilakukan untuk meningkatkan kemampuan penguasaan bahasa Inggris bagi siswa.

Berkaitan dengan komitmen Madrasah Ibtidaiyah Al-Kifayah Pekanbaru untuk meningkatkan kemampuan bahasa Inggris siswa, bantuan penanganan yang terencana dan terprogram kiranya sangat dibutuhkan. Untuk itulah program ini dirancang sebagai upaya untuk memberikan sumbangan yang bermanfaat bagi masyarakat, terutama bagi dunia pendidikan. Pelatihan Bahasa Inggris 'Penyamaan Persepsi Pembelajaran Bahasa Inggris antara Guru Bahasa Inggris dan Wali Murid bagi Anak usia Sekolah Dasar" ini diharapkan dapat membantu para siswa termotivasi dan merasa senang dalam belajar bahasa Inggris baik di sekolah maupun di rumah sehingga siswa mampu menggunakan bahasa Inggris dalam keseharian dan pendidikan.

Hasil riset dari Technology Brain Imaging University of California, Los Ageles secara biologis anak usia Sekolah Dasar adalah waktu yang tepat untuk mempelajari bahasa asing. Selain itu Hurlock (1993), Anak usia SD mampu memahami bahasa asing dg baik seperti halnya pemahaman terhadap bhs ibunya dalam 4 keterampilan berbahasa: mendengarkan, berbicara, membaca, $\&$ menulis. Oleh karena itu, anakanak usia SD secara biologis berada dalam masa emas untuk mempelajari Bahasa Inggris sebagai bahasa kedua setelah bahasa Indonesia. Oleh karena itu, waktu yang sangat tepat terutama bagi guru Bahasa Inggris dan orang tua atau wali murid untuk mendapatkan persepsi yang sama dalam mengajarkan bahasa Inggris agar dapat motivasi anak didiknya. Metode pembelajaran yang sesuai dengan usia anak Sekolah Dasar merupakan metode yang bisa digunakan untuk mengajarkan bahasa Inggris yang tepat seperti Listen and Repeat, Listen and Do, Question and Answer, Draw and Colour, Pemodelan dan Demonstrasi, See Differences, Word Chain Word Wall, Substituin, Cooperat Learning, and Mind Map \& Lapbook. Metode- 
ISSN : 2550-0198

metode tersebut adalah metode yang sangat efektif untuk digunakan anak usia Sekolah Dasar dalam mempelajari dan memahami bahasa Inggris dengan asyik dan santai, karena metode ini merupakan metode bermain sambil belajar. Adapun manfaat dari metode-metode tersebut bagi anak usia Sekolah dasar antara lain adalah:

1. Anak dapat fokus pada proses, kemasan materi pembelajaran, serta pembelajaran bahasa Inggris dapat diikuti oleh siswa secara menyenangkan.

2. Anak dapat ikut serta aktif proses pembelajaran karena metode yang digunakan dikemas khusus untuk anak usia Sekolah Dasar atau telah disesuaikan dengan usia mereka.

3. Dari segi kognitif, pembelajaran anak cenderung lebih kreatif dan mampu berpikir komplek karena dengan metode ini potensi kemampuan otak kiri salah satunya sebagai kecerdasan matematik dan rasional dapat terasah sehingga mereka dapat memecahkan permasalahan yg lebih rumit

4. Melalui metode-metode tersebut secara kepribadian, siswa lebih percaya diri dalam pembelajaran karena rasa ingin tahu mereka terbentuk sehingga timbul motivasi belajar yang lebih baik.

5. Ditinjau dari segi social, denagn metode ini anak dapat lebih terbuka terhadap perbedaan dan dapt memiliki kesempatan lebih banyak untuk berkomunikasi dengan sesamanya.

Berdasarkan penjelasan diatas, penerapan metode - metode tersebut bisa memberikan dampak yang sangat signifikan untuk pembelajaran bahasa Inggris dimana siswa sangat termotivasi dan merasa senang belajar bahasa Inggris sehingga mereka bisa dengan mudah menguasai bahasa Inggris.

\section{METODE PENGABDIAN}

Metode yang digunakan dalam kegiatan pelatihan ini adalah metode ceramah, diskusi, dan role play. 1) Metode Ceramah digunakan untuk menyampaikan materi secara rinci tentang persepsi pembelajaran bahasa Inggris kepada guru bahasa Inggris dan wali murid Madrasah Ibtidaiyah Ak-Kifayah, dan metode yang digunakan untuk mengajarkan bahasa Inggris sesuai usia anak Sekolah Dasar. 2) Metode Diskusi digunakan untuk mengakomodasi pertanyaan atau masukan tentang topik pada materi yang telah disampaikan. 3) metode Role Play digunakan untuk mempraktekkan metode pembelajaran bahasa Inggris pada anak usia Sekolah Dasar sehingga peserta pelatihan dapat memahami secara langsung bagaimana mengajarkan bahasa Inggris ke anak usia Sekolah dasar sehingga anak usia tersebut dapat dengan mudah memahami bahasa Inggris sejak awal dan dapat belajar tidak hanya di sekolah tetapi juga di rumah.

Kegiatan PPM diawali dengan perkenalan antara tim pelaksana dengan peserta pelatihan yaitu guru bahasa Inggris dan wali murid siswa Madrasah Ibtidaiyah Al-Kifayah Pekanbaru, yang dilanjutkan dengan pengenalan materi pelatihan kepada peserta latihan. Selanjutnya melakukan kegiatan proses pelatihan bahasa Inggris dengan metode pembelajaran yang telah dipilih yaitu terdapat 10 (sepuluh) metode sesuai dengan kebutuhan anak usia Sekolah dasar, diakhiri dengan review singkat, diskusi, dan praktek bagi 
peserta pelatihan bagaimana cara menyampaikan pembelajaran bahasa Inggris kepada anak dengan materi yang telah diberikan.

\section{HASIL DAN PEMBAHASAN}

Hasil kegiatan pengabdian kepada masyarakat ini mendapatkan sambutan yang sangat positif dari pihak mitra yakni Madrasah Ibtidaiyah Al-Kifayah Pekanbaru karena program ini sesuai dengan kebutuhan mereka. Bentuk sambutan yang sangat positif tersebut adalah terlihat dari partisipasi seluruh peserta pelatihan baik guru bahasa Inggris maupun wali murid yang hadir pada pelatihan tersebut sangat aktif dalam mengikuti seluruh proses kegiatan. Antusiame ini juga tergambar dari banyaknya peserta yang ikut berpartisipasi ketika diminta maju ke depan para peserta lainnya untuk mempraktekkan metode pembelajaran bahasa Inggris yang telah diberikan untuk anak usia Sekolah Dasar.

Seluruh peserta pelatihan memiliki motivasi yang tinggi yaitu dengan sangat antusianya mereka dalam kegiatan pelatihan. Hal tersebut mengindikasikan bahwa adanya kesadaran para peserta pelatihan dalam memahami pentingnya siswa belajar bahasa Inggris sejak dini atau di awal usia Sekolah Dasar. Peningkatan kemampuan anak didik terhadap penguasaan skil bahasa Inggris terutama di era modern saat ini dimulai dari para pengajar di sekolah yaitu guru bahasa Inggris dan wali murid ketika anak-anak berada di rumah. Hal ini dikarenakan bahasa Inggris merupakan skil yang harus dimiliki setiap orang untuk dapat memahami berbagai bidang keilmuan serta teknologi informasi agar mampu bersaing.

Upaya yang dilakukan pihak sekolah Madrasah Ibtidaiyah AlKifayah selama ini agar para siswa memiliki kemampuan bahasa Inggris dengan baik salah satunya adalah dengan membekali para pengajar dengan pelatihan dibidang keahlian juga kemahiran guru dalam menggunakan metode pengajaran. Peningkatan pemahaman tentang bahasa Inggris bagi sekolah adalah dengan cara meningkatkan kualitas guru. Sedangkan upaya pihak sekolah meningkatkan skil bahasa Inggris siswa tidak hanya para guru bahasa Inggris saja tetapi juga peran para wali murid sehingga hal tersebut juga dipandang perlu diberikan pelatihan mengenai metode cara mengajarkan bahasa Inggris, dan menyamakan cara pandang orang tua dalam pembelajaran agar sama-sama memahami pentingnya bahasa Inggris diajarkan kepada siswa sejak awal di usia Sekolah Dasar karena di usia ini adalah usia yang paling tepat anak belajar bahasa asing terutama bahasa Ingris.

Berdasarkan hasil yang didapat dari kegiatan pengabdian pada masyarakat (PPM) yang telah dipaparkan, bahwa kegiatan pengabdian ini mendapat respon yang sangat baik dari para peserta. Guru bahasa Inggris dan wali murid Madrasah Ibtidaiyah Al-Kifayah Pekanbaru khususnya yang mayoritas tidak memiliki latar belakang pengetahuan bahasa Inggris juga ikut andil secara aktif dalam setiap sesi kegiatan.

Kegiatan yang di ikuti oleh peserta pengabdian berjalan dengan baik meskipun ada beberapa peserta 
ISSN : 2550-0198

yang tidak memiliki latar belakang pengetahuan tentang bahasa Inggris sama sekali, namun kerjasama yang baik dan proaktif diantara para peserta yang sangat antusias mempraktekkan kemampuannya dengan bersungguh-sungguh mempraktekkan cara mengajarkan bahasa Inggris pada anak usia sekolah Dasar di depan peserta lain dengan bekal materi yang sudah diberikan pada pelatihan tersebut, maka hal tersebut dapat menyelesaikan masalah yang dihadapi selama proses berlangsung. Keberhasilan kegiatan pengabdian ini terlihat dari adanya kemauan atau kesungguhan yang tinggi yang ditunjukkan oleh peserta melalui kegiatan selama proses berlangsung. Hal ini menunjukkan bahwa mereka merasakan manfaat dari adanya kegiatan pengabdian ini sehingga mereka menganggap penting pembelajaran bahasa Inggris diberikan kepada anak sejak awal.

\section{SIMPULAN}

Pengabdian pada masyarakat yang dilakukan bertujuan untuk memberikan gambaran tentang cara pandang/persepsi yang sama antara guru bahasa Inggris dan wali murid terhadap pentingnya pembelajaran bahasa Inggris pada anak usia sekolah dasar, hal tersebut dilakukan agar memudahkan mereka dalam memberikan motivasi kepada siswa atau anak-anak usia Sekolah Dasar tersebut untuk memahami bahasa Inggris terutama pada materi-materi dasar dengan metode pembelajaran bahasa Inggris yang telah diberikan sebagai dasar pemahaman awal bahasa Inggris.

Berdasarkan tujuan tersebut, maka target riil yang ingin dicapai selanjutnya adalah memotivasi siswa untuk dapat mengembangkan potensi atau kemampuan pemahaman bahasa Inggris sejak awal dengan menyamakan persepsi antara guru bahasa Inggris dan wali murid agar siswa terus termotivasi dalam belajar bahasa Inggris di Sekolah maupun di rumah. Untuk mencapai tujuan dan target dari kegiatan pengabdian pada masyarakat (PPM) tersebut, maka pelaksana menggunakan metode ceramah, diskusi, dan role play agar peserta pelatihan dapat mudah memahami materi yang diberikan pada pelatihan tersebut. Selain itu, pada pelatihan ini juga peserta diberikan metode-metode pengajaran bahasa Inggris untuk anak usia sekolah dasar agar mereka dapat mempraktekkan secara langsung materi yang didapatkan. Adapun metode pembelajaran bahasa Inggris yang dipilih dan diberikan kepada peserta pelatihan sesuai usia anak Sekolah Dasar yaitu Listen and Repeat, Listen and Do, Question and Answer, Draw and Colour, Modelling and Demonstration, See Differences, Word Chain Word Wall, Substituin, Cooperat Learning, and Mind Map \& Lap book. Kegiatan yang dilaksanakan diikuti oleh guru bahasa Inggris dan wali murid Madrasah Ibtidaiyah AlKifayah Pekanbaru. Para peserta pelatihan sangat antusias dalam mengikuti pelatihan tersebut, hal ini dibuktikan dengan banyaknya peserta yang ingin mencoba mempraktekkan secara langsung metode pembelajaran bahasa Inggris di depan peserta lain, selain itu hampir seluruh peserta aktif dalam sesi diskusi.

\section{UCAPAN TERIMAKASIH}

Ucapan terimakasih diberikan kepada Bapak/Ibu/Sdr atas 
kesediannya membantu terlaksananya kegiatan Pengabdian Pada Masyarakat (PPM) yaitu kepada:

1. Rektor Universitas Muhammadiyah Riau

2. Dekan Fakultas Keguruan dan Ilmu Pendidikan UMRI

3. Ketua Lembaga Penelitian dan Pengabdian Masyarakat (LPPM) UMRI

4. Kepala Sekolah Madrasah Ibtidaiyah Al-Kifayah Pekanbaru

5. Pihak-pihak yang tidak dapat kami sebutkan namanya yang telah banyak membantu terlaksananya PPM.

\section{DAFTAR PUSTAKA}

[1] Cahyono, bambang Yudi. 1997. Pengajaran Bahasa Inggris. Malang: Penerbit IKIP Malang.

[2] Suhartono. 2005. Pengembangan Keterampilan Bicara Anak Usia Dini. Jakarta: Diknas

[3] Suyanto, Kasihani K.E. 2008. English For Young Learners. Jakarta: Bumi Aksara

[4] Brown, H.D. (1994). Principles of Language Learning and Teaching. Englewood Cliffs, N.J.: Prentice Hall

[6] Dubin. F. Olstain. E (1990). Course Design developing
Program and Materials for Language Learning. Cambridge: Cambridge University press

[7] Milafaila. 2011. Pemanfaatan Media Audio Visual sebagai Upaya untuk Meningkatkan Penguasaan Bahasa Inggris Anak Usia Dini. (Online) https://failashofagmail.wordpre ss.com/2011/06/08/modelpembelajaran-aud/. Diakses 18 februari 2017.

[8] Mulyadin, Taufik. 2012. Bahasa Inggris dan Pembentukan Karakter Anak Sejak Dini. (Online) http://pojokkangadin.blogspot. co.id/2012/02/bahasa-inggrisdan-pembentukan-

karakter.html. Diakses 18 februari 2017

[9] RAHMULIA, Frima (2014) Persepsi Stakeholder Pendidikan di Kota Tasikmalaya Mengenai dihapusnya Pelajaran Bahasa Inggris dalam Kurikulum Sekolah dasar 2013. UPI Kampus Tasikmalaya. PGSD UPI Kampus Tasikmalaya, http://repository.upi.edu/id/epri nt/1169. 21 februari 2017 